\title{
Analisis Tingkat Kesejahteraan Masyarakat di Provinsi Nusa Tenggara Barat Menggunakan Model Regresi Multivariat
}

\author{
Rahmat Syam ${ }^{1, a),}$, Sukarna ${ }^{1, b),}$ dan Nurmah ${ }^{1, c)}$ \\ ${ }^{1}$ Jurusan Matematika FMIPA Universitas Negeri Makassar, 90224 \\ a)rahmat.syam@unm.ac.id \\ b)sukarna@unm.ac.id \\ c)nurmahra@gmail.com
}

\begin{abstract}
Abstrak. Penelitian ini bertujuan untuk mengetahui model hubungan antara laju Pertumbuhan Ekonomi, tingkat Produk Domestik Regional Bruto per kapita, dan Indeks Pembangunan Manusia terhadap variabelvariabel penunjang berdasarkan analisis regresi multivariat dalam menganalisis tingkat kesejahteraan masyarakat di Provinsi Nusa Tenggara Barat dengan pemilihan model terbaik menggunakan metode KICC. Variabel-variabel penunjang tersebut adalah angka harapan hidup, tingkat pengangguran terbuka, pengeluaran perkapita, tingkat kemiskinan, dan pendapatan asli daerah. Data tersebut dipublikasikan oleh Badan Pusat Statistik Provinsi Nusa Tenggara Barat tahun 2018. Pada penelitian ini diperoleh bahwa terdapat tiga variabel yang berpengaruh positif terhadap kesejahteraan masyarakat di Provinsi Nusa Tenggara Barat yaitu angka harapan hidup, pengeluaran perkapita, dan pendapatan asli daerah. Sedangkan dua variabel lainnya berpengaruh negatif. Adapun hubungan antara variabel-variabel prediktor terhadap variabel respon secara simultan adalah sebesar $\eta_{\Lambda}^{2}=0,999990324$, hal ini berarti bahwa model dapat menjelaskan informasi data sebesar 99,99\%.
\end{abstract}

Kata kunci: Kesejahteraan, Analisis Regresi multivariat, KICC

\begin{abstract}
This study aims to determine the model of the relationship between the rate of economic growth, the level of Gross Domestic Product Regional each capita, and the Human Development Index for supporting variables base on multivariate regression analysis to analyze the level of public welfare in West Nusa Tenggara Province by selecting the best model using the KICC method. The supporting variables were life expectancy, unemployment rate, expenditure each capita, poverty level, and local income. The data was published by the Central Bureau of Statistics of West Nusa Tenggara Province on 2018. The result shows that there are three variables which have shown a positive impact on the public welfare in West Nusa Tenggara Province, namely life expectancy, expenditure each capita, and local income. However, the others have shown a negative impact. The relation between predictors and response simultaneously is $\eta_{\Lambda}^{2}$ $=0.999990324$, it means that the data is explainable $99.99 \%$ by the model .
\end{abstract}

Keywords: Welfare, Analysis of e Regression, KICC.

\section{PENDAHULUAN}

Kesejahteraan adalah kondisi agregat dari kepuasan individu-individu. Kesejahteraan sosial adalah mencakup berbagai tindakan yang dilakukan manusia untuk mencapai tingkat kehidupan masyarakat yang lebih baik (Sinaga, 2016). Kesejahteraan masyarakat mencerminkan kualitas hidup dari sebuah keluarga. Keluarga dengan tingkat kesejahteraan lebih tinggi berarti memiliki kualitas hidup yang lebih baik (Rosni, 2017). 
Kesejahteraan masyarakat merupakan suatu konsep multi indikator yang menunjukkan ukuran keberhasilan pembangunan di suatu wilayah. Kesejahteraan masyarakat suatu negara dari sudut pandang ekonomi diukur melalui instrumen pertumbuhan ekonomi, Produk Domestik Regional Bruto (PDRB) per kapita, dan Indeks Pembangunan Manusia (IPM) (Limbong \& Setyawan, 2018).

Provinsi Nusa Tenggara Barat (NTB) adalah provinsi yang terdiri dari 10 kabupaten/kota. Keanekaragaman sumber daya alam yang melimpah berpotensi untuk meningkatkan perekonomian wilayah. Rata-rata pertumbuhan ekonomi yang dicapai oleh Provinsi NTB pada tahun 2016 yaitu sebesar 5,82 persen, relatif lebih tinggi dibandingkan dengan rata-rata pertumbuhan ekonomi nasional di Indonesia yaitu sebesar 5,02 persen. Berdasarkan data Susenas Provinsi NTB tahun 2009-2016. Peningkatan ini mengindikasikan bahwa rata-rata pendapatan penduduk NTB mengalami peningkatan dari tahun ke tahun. Angka IPM Provinsi NTB pada tahun 2016 mencapai 65,81 persen, mengalami kenaikan dari tahun 2015 dan berada pada klasifikasi kesejahteraan sedang. Posisi IPM NTB berada pada posisi ke 30 dari 34 provinsi yang ada di Indonesia (BPS Provinsi NTB, 2016).

Berdasarkan indikator-indikator tersebut, dapat dibuat suatu model regresi multivariat yang digunakan untuk menduga faktor-faktor penunjang tingkat kesejahteraan masyarakat. Pemilihan model terbaik menggunakan metode Kullback's Information Criterion Correction (KICC). Kriteria KICC merupakan penyempurnaan dari kriteria AIC dan AICC (Limbong \& Setyawan, 2018).

Model regresi multivariat merupakan model regresi dengan $\mathrm{q}$ buah variabel respon $Y_{1}, Y_{2}, Y_{3}, \ldots, Y_{q}$ yang saling berkorelasi dan satu atau beberapa variabel prediktor $X_{1}, X_{2}, X_{3}, \ldots, X_{q}$. Pada model regresi multivariat diasumsikan adanya hubungan ketergantungan di antara variabel respon (Johnson \& Wichern, 1998; Rencher, 2002).

Beberapa peneliti telah melakukan penelitian tentang pemakaian model regresi multivariat. Limbong dan Setyawan (2018) membahas tentang faktor-faktor yang mempengaruhi kesejahteraan masyarakat provinsi Sumatera Utara. Penelitian ini menggunakan kriteria KICC sebagai metode pemilihan model terbaik. Mardianto dan Wahyuningsih (2013) membahas tentang model regresi multivariat yang dibentuk untuk kesejahteraan kabupaten/kota di Jawa Timur. Selanjutnya Oleh Rosni (2017) yang membahas mengenai tingkat kesejahteraan masyarakat nelayan di Desa Dahari Selebar Kecamatan Talawi Kabupaten Batubara. Penelitian ini menunjukkan responden-responden dinyatakan miskin karena penghasilan para nelayan masih dibawah UMK.

Pada penelitian ini dilakukan pengujian model regresi multivariat yang dibentuk untuk menganalisi kesejahteraan masyarakat di provinsi NTB dengan menggunakan kriteria koreksi KICC. Tujuan penelitian ini adalah untuk mengetahui variabel-variabel yang dapat dijadikan penunjang kesejahteraan masyarakat. Selain itu, penelitian ini bertujuan untuk mengetahui bentuk model matematika yang cocok dalam menganalisis tingkat kesejahteraan masyarakat di provinsi NTB.

\section{LANDASAN TEORI}

\section{Analisis Regresi Multivariat}

Analisis regresi multivariat adalah analisis yang mempelajari hubungan fungsional antara dua peubah atau lebih. Dalam analisis regresi dibedakan dua jenis peubah, yaitu peubah bebas (independet variable) dan peubah terikat (dependent variable). Peubah bebas disebut juga peubah peramal (predictor variable), sedangkan peubah terikat disebut peubah tanggapan (response variable). Peubah peramal dijadikan penduga terhadap peubah tanggapan (Tiro, 2007). 
Analisis regresi linier multivariat mempertimbangkan adanya hubungan ketergantungan di antara $Y_{1}, Y_{2}, \cdots, Y_{q}$. Pada analisis regresi linier multivariat pemilihan model terbaik merupakan hal yang penting. Hal ini dikarenakan tidak semua variabel prediktor berpengaruh nyata terhadap model (Sumaya, 2014).

Model regresi linier multivariat adalah model regresi linier dengan lebih dari satu variabel respon $(Y)$ yang saling berkorelasi dan satu atau lebih variabel bebas $(X)$. Misalkan terdapat variabel respon berjumlah $q$ yaitu $Y_{1}, Y_{2}, \cdots, Y_{q}$ dan $p$ variabel prediktor yaitu $X_{1}, X_{2}, \cdots, X_{p}$, maka diperoleh model dari regresi linier multivariat untuk pengamatan ke- $i$ respon ke- $j$ adalah (Rencher, 2002):

$$
\begin{gathered}
Y_{i 1}=\beta_{01}+\beta_{11} X_{i 1}+\cdots+\beta_{p 1} X_{i p}+\varepsilon_{i 1} \\
Y_{i 2}=\beta_{02}+\beta_{12} X_{i 1}+\cdots+\beta_{p 2} X_{i p}+\varepsilon_{i 2} \\
\quad \vdots \\
Y_{i j}=\beta_{0 j}+\beta_{1 j} X_{i 1}+\cdots+\beta_{p j} X_{i p}+\varepsilon_{i j}
\end{gathered}
$$

dengan $i=1,2, \cdots, n$ dan $j=1,2, \cdots, q$. Dimana $Y_{i j}$ merupakan nilai amatan ke $-i$ untuk variabel respon $\mathrm{ke}-j, X_{i p}$ adalah nilai amatan $\mathrm{ke}-i$ untuk variabel respon $\mathrm{ke}-p$.

Model regresi multivariat yang terdiri dari $q$ variabel respon, $p$ variabel prediktor dengan jumlah pengamatan sebesar $n$ secara simultan dapat ditunjukkan dengan bentuk matriks sebagaimana pada persamaan berikut:

$$
Y_{(n x q)}=X_{n x(p+1)} \beta_{(p+1) x q}+\varepsilon_{(n x q)}
$$

\section{Uji Kebebasan Antar Variabel Respon}

Variabel $q Y_{1}, Y_{2}, \ldots, Y_{q}$ dikatakan bersifat saling bebas (independent) jika matriks korelasi antar variabel membentuk matriks identitas. Untuk menguji kebebasan antar variabel ini dapat dilakukan uji Bartlett Sphericity (Morrison, 2005) dapat dijelaskan sebagai berikut:

Hipotesis:

$\mathrm{H}_{0}$ : Antar variabel respon bersifat independent.

$\mathrm{H}_{1}$ : Antar variabel respon bersifat dependent.

Statisitk uji:

$$
X_{\text {hitung }}^{2}=-\left(n-1-\frac{2 q+5}{6}\right) \ln |R|
$$

Kriteria uji:

$X_{\text {hitung }}^{2} \leq X_{\text {tabel }}^{2}=X_{a, \frac{1}{2} q(q-1)}^{2}$, Terima $\mathrm{H}_{0}$ sehingga antar variabel respon independen.

\section{Pengujian Berdistribusi Normal Variabel Respon}

Asumsi lain yang harus dipenuhi dalam analisis regresi multivariat adalah variabel respon berdistribusi normal (Rencher, 2002). Pengujian normal dilakukan dengan hipotesis:

$\mathrm{H}_{0}$ : Data berdistribusi normal.

$\mathrm{H}_{1}$ : Data tidak berdistribusi normal.

Statistik uji:

dengan $i=1,2, \ldots, n$

$$
d_{i}^{2}=\left(y_{i}-\bar{y}\right)^{T} S^{-1}\left(y_{i}-\bar{y}\right)
$$

Kriteria uji:

Jika diperoleh kondisi dimana $d_{i}^{2} \leq x_{\text {tabel }}^{2}=x_{q, \frac{1}{2}}^{2}$ terhadap lebih dari $\frac{1}{2} n$ sampel, maka $\mathrm{H}_{0}$ diterima sehingga data dikatakan berdistribusi normal. 


\section{Estimasi Parameter Regresi Multivariat}

Dalam model regresi multivariat dapat dikelompokkan bahwa $\boldsymbol{Y}$ merupakan matriks yang berisi komponen variabel-variabel respon. $\boldsymbol{X}$ merupakan matriks yang berisi komponen variabelvariabel prediktor. $\boldsymbol{\beta}$ adalah suatu matriks yang berisi komponen parameter regresi multivariat dengan ukuran $(p+1) \times q$, dengan estimasi:

$$
\widehat{\beta}=\left(X^{T} X\right)^{-1} X^{T} Y
$$

sedangkan $\boldsymbol{\varepsilon}$ merupakan matriks yang berisi komponen residual data yang ditentukan oleh estimasi:

(Rencher, 2002).

$$
\widehat{\boldsymbol{\varepsilon}}=\boldsymbol{Y}-\boldsymbol{X} \widehat{\boldsymbol{\beta}}
$$

\section{Kullback's Information Criterion Corrected (KICC)}

Hafidi dan Mkhadri (2006) menjelaskan bahwa kriteria KICC (Kullback's Information Criterion Corrected) memiliki ketetapan prediksi yang lebih tinggi saat diterapkan pada sampel kecil. Besarnya KICC dapat ditentukan sebagaimana pada persamaan berikut:

$$
K I C C=n(\ln |\hat{\Sigma}|+q)+\frac{d\left(3_{n}-p-q-1\right)}{n-p-q-1}
$$

Dimana:

$d=q p+0,5 q(q+1)$.

$q=$ jumlah variabel respon.

$p=$ jumlah parameter.

$n=$ jumlah data.

$\widehat{\Sigma}=$ penaksir matriks varian-kovarian.

Kriteria pemilihan model terbaik jika didapatkan nilai KICC terkecil. Hal ini berarti semakin kecil nilai dari KICC (positif terkecil atau negative terbesar) maka semakin baik model yang digunakan.

\section{Pengujian Signifikasi Model}

\section{Pengujian Serentak}

Pengujian secara serentak bertujuan untuk mengetahui bagaimana pengaruh semua variabel prediktor secara bersamaan terhadap variabel respon. Pengujian ini juga dilakukan untuk mengetahui apakah secara keseluruhan parameter signifikan dalam model (Rencher, 2002).

Hipotesis:

$\mathrm{H}_{0}: \hat{\beta}_{11}=\hat{\beta}_{12}=\cdots=\hat{\beta}_{p 1}=\cdots=\hat{\beta}_{p q}=0$, model tidak signifikan.

$\mathrm{H}_{1}$ : Paling sedikit ada satu $\beta_{p, q} \neq 0$, model signifikan.

Dimana $p=1,2, \ldots$, banyak prediktor dan $q=1,2, \ldots$, banyak variabel respon.

Statistik Uji:

$$
\Lambda=\frac{|E|}{|E+H|}=\frac{\left|Y^{T} Y-\beta^{T} X^{T} Y\right|}{\left|Y^{T} Y-n \bar{y} \bar{y}^{T}\right|}
$$

$\Lambda$ adlah nilai Wilk's Lambda, $\bar{y}$ adalah vector rata-rata $Y$.

Kriteria Uji:

Jika $\Lambda_{\text {hitung }} \leq \Lambda_{\alpha, p, q, n-p-1}$ maka $\mathrm{H}_{0}$ ditolak, dimana secara keseluruhan parameter tidak sama dengan nol sehingga model signifikan. Nilai $\Lambda_{\alpha, p, q, n-p-1}$ adalah nilai kritis untuk Wilk's Lambda. 


\section{Pengujian Parsial}

Pengujian ini bertujuan untuk melihat pengaruh signifikan setiap variabel prediktor terhadap variabel-variabel respon secara persial. Untuk menguji syarat ini dapat ditentukan sebagaimana pada persamaan berikut (Rencher, 2002):

Hipotesis:

$\mathrm{H}_{0}: \hat{\beta}_{j k}=0$ Parameter regresi prediktor ke- $j$ tidak berpengaruh secara signifikan terhadap respon $k$.

$\mathrm{H}_{1}$ : Paling sedikit ada satu $\hat{\beta}_{j k} \neq 0$ parameter regresi prediktor $j$ terhadap respon $k$ berpengaruh secara signifikan.

Dimana $j=1,2, \ldots$, banyak prediktor dan $k=1,2, \ldots$, banyak variabel respon.

Statistik Uji:

$$
\Lambda=\frac{|E|}{|E+H|}=\frac{\left|Y^{T} Y-\beta^{T} X^{T} Y\right|}{\left|Y^{T} Y-\widehat{\beta}_{j}^{T} X_{j}^{T} Y\right|}
$$

Kriteria uji:

$\Lambda_{\text {hitung }} \leq \Lambda_{\alpha, p, q, n-p-1} \rightarrow$ Tolak $\mathrm{H}_{0}$, dimana secara keseluruhan parameter tidak sama dengan nol sehingga variabel prediktor ke- $j$ berpengaruh signifikan terhadap variabel respon yang ada secara parsial.

\section{Uji Asumsi Residual}

\section{Uji Asumsi Residual Identik}

Asumsi yang harus dipenuhi dalam melakukan pemodelan regresi multivariat adalah residual memiliki matriks varian-kovarian yang homogen. Untuk menguji syarat ini dapat dipergunakan statistik uji Box's M. (Rencher,2002).

Hipotesis:

$\mathrm{H}_{0}: \Sigma_{1}=\Sigma_{2}=\cdots=\Sigma_{k}=\Sigma$

$\mathrm{H}_{1}:$ minimal ada satu $\Sigma_{i} \neq \Sigma_{j}$ untuk $i \neq \mathrm{j}$

Statistik uji:

Kriteria uji:

$$
u=-2\left(1-c_{1}\right) \ln M
$$

Jika $u \leq x_{\text {tabel }}^{2}=x_{a, \frac{1}{2}(k-1) p(p+1)}^{2}$ maka $\mathrm{H}_{0}$ diterima, yang berarti matriks-matriks variankovarian residual adalah homogen dan dapat disimpulkan bahwa terjadi residual identik.

\section{Uji Asumsi Residual Independent}

Untuk menguji kebebasan antar residual dapat dilakukan uji Bartlett Sphericity dengan langkah yang sama seperti pengujian kebebasan variabel respon.

Hipotesis:

$\mathrm{H}_{0}$ : Residual bersifat independen.

$\mathrm{H}_{1}$ : Residual bersifat dependen.

Statistik Uji:

$$
X_{\text {hitung }}^{2}=-\left(n-1-\frac{2 q+5}{6}\right) \ln |R|
$$

Kriteria uji:

$X_{\text {hitung }}^{2} \leq X_{\text {tabel }}^{2}=X_{a, \frac{1}{2} q(q-1)}^{2}$, Terima $\mathrm{H}_{0}$ sehingga residual independent. 


\section{Uji Asumsi Residual Berdistribusi Normal}

Untuk menguji asumsi residual berdistribusi normal juga digunakan prosedur yang sama seperti pengujian variabel respon berdistribusi normal.

Hipotesis:

$\mathrm{H}_{0}$ : Residual berdistribusi normal.

$\mathrm{H}_{1}$ : Residual tidak berdistribusi normal.

Statistik uji:

dengan $i=1,2, \ldots, n$.

$$
d_{i}^{2}=\left(y_{i}-\bar{y}\right)^{T} S^{-1}\left(y_{i}-\bar{y}\right)
$$

Kriteria uji:

Jika diperoleh kondisi dimana $d_{i}^{2} \leq x_{\text {tabel }}^{2}=x_{q, \frac{1}{2}}^{2}$ terhadap lebih dari $\frac{1}{2} n$ sampel, maka $\mathrm{H}_{0}$ diterima sehingga data dikatakan berdistribusi normal.

\section{Hubungan Antar Variabel Dalam Model}

Pada regresi multivariat, ukuran yang digunakan untuk mengukur hubungan antara variabel respon dan prediktor adalah Wilk's Lambda. Ukuran dinyatakan dengan rumus sebagai berikut:

$$
\eta_{\Lambda}^{2}=1-\Lambda
$$

Dengan $\Lambda$ adalah nilai Wilk's lambda (Rencher, 2002).

Nilai $\eta_{\Lambda}^{2}$ adalah nilai keterkaitan antara variabel respon dan prediktor, berada pada interval 0 dan 1. Artinya, semakin mendekati 1 berarti hubungan antara variabel respon dan variabel prediktor semakin erat.

\section{METODE PENELITIAN}

Penelitian ini digolongkan dalam jenis penelitian terapan (applied research) dengan menggunakan data sekunder. Penelitian ini bertujuan untuk mengetahui variabel-variabel yang dapat dijadikan indikator untuk menganalisis tingkat kesejahteraan masyarakat di Provinsi NTB. Selain itu, penelitian ini bertujuan untuk mengetahui bentuk model matematika dari regresi multivariat yang cocok digunakan dalam menganalisis. Penelitian ini menggunakan data informasi yang diperoleh dari publikasi Badan Pusat Statistik Provinsi NTB pada tahun 2018.

\section{HASIL PENELITIAN}

\section{Statistik Deskriptif}

Dalam penelitian ini statistik deskriptif yang digunakan adalah nilai rata-rata, nilai maksimum, dan nilai minimum. Variabel respon dalam penelitian ini yaitu persentase tingkat Pertumbuhan Ekonomi $\left(Y_{1}\right)$, persentase tingkat Produk Domestik Regional Bruto per kapita $\left(Y_{2}\right)$, dan Indeks Pembangunan Manusia $\left(Y_{3}\right)$. Statistik deskriptif variabel respon bertujuan untuk mengetahui karakteristik dari masing-masing variabel respon. Statistik deskriptif variabel respon dapat dilihat sebagaimana Tabel 1:

TABEL 1. Statistik Deskriptif Variabel Respon

\begin{tabular}{clll}
\hline Variabel & Rata-rata & Minimal & Maksimal \\
\hline $\boldsymbol{Y}_{\mathbf{1}}$ & 0,461 & $-24,08$ & 4,98 \\
$\boldsymbol{Y}_{\mathbf{2}}$ & 24,722 & 11,55 & 90,42 \\
$\boldsymbol{Y}_{\mathbf{3}}$ & 68,526 & 63,83 & 78,43 \\
\hline
\end{tabular}


Variabel prediktor dalam penelitian ini yaitu angka harapan hidup $\left(X_{1}\right)$, persentase tingkat pengangguran terbuka $\left(X_{2}\right)$, pengeluaran per kapita $\left(X_{3}\right)$, persentase kemiskinan $\left(X_{4}\right)$ dan persentase anggaran pendapatan asli daerah $\left(X_{5}\right)$. Statistik deskriptif variabel prediktor dapat dilihat sebagaimana Tabel 2.

TABEL 2. Statistik Deskriptif Variabel Prediktor

\begin{tabular}{clll}
\hline Variabel & Rata-rata & Minimal & Maksimal \\
\hline $\boldsymbol{X}_{\mathbf{1}}$ & 67,081 & 65,33 & 71,24 \\
$\boldsymbol{X}_{\mathbf{2}}$ & 3,698 & 2,39 & 6,72 \\
$\boldsymbol{X}_{\mathbf{3}}$ & 10,258 & 8,35 & 14,80 \\
$\boldsymbol{X}_{\mathbf{4}}$ & 14,776 & 8,79 & 28,87 \\
$\boldsymbol{X}_{\mathbf{5}}$ & 99,134 & 65,54 & 146,64 \\
\hline
\end{tabular}

\section{Pembentukan Model Regresi Multivariat}

\section{Pengujian Kebebasan Antar Variabel Respon}

Sebelum dibentuk suatu model regresi multivariat, terlebih dahulu dilakukan pengujian kebebasan antar variabel respon dan pengujian normal variabel respon. Jika variabel respon tidak saling berhubungan, maka analisis dilanjutkan dengan menggunakan regresi multivariat univariat. Jika sebaliknya terdapat hubungan antar variabel respon, maka analisis akan dilanjutkan dengan menggunakan regresi multivariat (Johnson\&Wichern,2007).

Uji yang digunakan untuk mengetahui kebebasan antar variabel respon adalah uji Bartlett Sphericity pada persamaan (2), hasil yang diperoleh yaitu sebagai berikut:

$$
\begin{aligned}
X_{\text {hitung }}^{2} & =-\left(n-1-\frac{2 q+5}{6}\right) \ln |R| \\
& =-\left(10-1-\frac{2(3)+5}{6}\right) \ln \left|\begin{array}{ccc}
1 & -0,937 & -0,040 \\
-0,937 & 1 & 0,293 \\
-0,040 & 0,293 & 1
\end{array}\right| \\
& =11,3095 \\
X_{\text {tabel }}^{2} & =X_{0,05, \frac{1}{2} 3(3-1)}^{2}=X_{0,05,3}^{2}=7,815
\end{aligned}
$$

Oleh karena nilai $X_{\text {hitung }}^{2}$ untuk ketiga variabel respon lebih besar dari nilai $X_{\text {tabel }}^{2}$ maka kesimpulannya tolak $\mathrm{H}_{0}$ atau antar variabel respon saling berkorelasi.

\section{Distribusi Normal Antar Variabel Respon}

Analisis yang digunakan adalah dengan menggunakan nilai square distance $\left(d_{i}^{2}\right)$ pada persamaan (3). Berdasarkan hasil pengujian yang dilakukan, maka didapatkan nilai $d_{i}^{2}$ sebagaimana Tabel 3.

TABEL 3. Statistik Uji untuk $d_{i}^{2}$ Variabel Respon

\begin{tabular}{cccc}
\hline $\mathbf{i}$ & $\mathbf{d}_{\mathbf{i}}^{\mathbf{2}}$ & $\mathbf{i}$ & $\mathbf{d}_{\mathbf{i}}^{\mathbf{2}}$ \\
\hline 1 & 0,18996 & 6 & 0,40847 \\
2 & 0,55291 & 7 & 7,92706 \\
3 & 0,59123 & 8 & 0,99288 \\
4 & 0,13663 & 9 & 4,61462 \\
5 & 0,12453 & 10 & 2,46172 \\
\hline
\end{tabular}

Berdasarkan Tabel 3 nilai $d_{i}^{2}<X_{\text {tabel }}^{2}\left(X_{3, \frac{1}{2}}^{2}\right)=2,366$ terhadap 7 pengamatan atau sebesar $70 \%$ dari 10 pengamatan. Berdasarkan hal tersebut, maka gagal menolak $\mathrm{H}_{0}$ sehingga variabel respon dikatakan berdistribusi normal. 


\section{Estimasi Parameter Regresi Multivariat}

Dalam analisis regresi multivariat ditentukan estimasi parameter regresi multivariat menggunakan persamaan (4) sehingga diperoleh:

$$
\widehat{\boldsymbol{\beta}}=\left(\boldsymbol{X}^{\boldsymbol{T}} \boldsymbol{X}\right)^{-1} \boldsymbol{X}^{\boldsymbol{T}} \boldsymbol{Y}=\left[\begin{array}{ccc}
-32,4987 & -7,0798 & -48,9707 \\
2,2106 & -3,0548 & 1,6146 \\
6,6420 & -11,9527 & -0,5331 \\
-7,6274 & 15,5082 & 0,8945 \\
-1,4584 & 2,4070 & -0,1140 \\
-0,4045 & 0,8703 & 0,0370
\end{array}\right]
$$

Nilai parameter $\beta$ dapat dimasukkan ke dalam model regresi multivariate pada persamaan (1), sehingga didapatkan model sebagai berikut:

$$
\begin{aligned}
& Y_{1}=-32,4987+2,2106 X_{1}+6,6420 X_{2}-7,6274 X_{3}-1,4584 X_{4}-0,4045 X_{5} \\
& Y_{2}=-7,0798-3,0548 X_{1}-11,9527 X_{2}+15,5082 X_{3}+2,4070 X_{4}+0,8703 X_{5} \\
& Y_{3}=-48,9707+1,6146 X_{1}-0,5331 X_{2}+0,8945 X_{3}-0,1140 X_{4}+0,0370 X_{5}
\end{aligned}
$$

\section{Pemilihan Model Terbaik dengan Menggunakan Metode Kullback's Information Criterion Corrected (KICC)}

Untuk mendapatkan nilai KICC terlebih dahulu menghitung nilai varians kovarians error $(\Sigma)$ dari masing-masing kombinasi prediktor yang telah diregresikan pada persamaan (7), hasilnya dapat dilihat sebagaimana Tabel 4:

TABEL 4. Nilai KICC Variabel Prediktor

\begin{tabular}{cccccc}
\hline No & Prediktor & KICC & No & Prediktor & KICC \\
\hline 1 & $X_{1}$ & 554,208 & 17 & $X_{1} X_{2} X_{4}$ & 523,971 \\
2 & $X_{2}$ & 575,437 & 18 & $X_{1} X_{2} X_{5}$ & 547,015 \\
3 & $X_{3}$ & 564,758 & 19 & $X_{1} X_{3} X_{4}$ & 525,755 \\
4 & $X_{4}$ & 569,862 & 20 & $X_{1} X_{3} X_{5}$ & 540,431 \\
5 & $X_{5}$ & 575,502 & 21 & $X_{1} X_{4} X_{5}$ & 530,028 \\
6 & $X_{1} X_{2}$ & 552,286 & 22 & $X_{2} X_{3} X_{4}$ & 548,771 \\
7 & $X_{1} X_{3}$ & 548,720 & 23 & $X_{2} X_{3} X_{5}$ & 553,577 \\
8 & $X_{1} X_{4}$ & 532,229 & 24 & $X_{2} X_{4} X_{5}$ & 560,784 \\
9 & $X_{1} X_{5}$ & 547,442 & 25 & $X_{3} X_{4} X_{5}$ & 556,024 \\
10 & $X_{2} X_{3}$ & 558,772 & 26 & $X_{1} X_{2} X_{3} X_{4}$ & 513,528 \\
11 & $X_{2} X_{4}$ & 564,837 & 27 & $X_{1} X_{2} X_{3} X_{5}$ & 527,570 \\
12 & $X_{2} X_{5}$ & 572,194 & 28 & $X_{1} X_{2} X_{4} X_{5}$ & 522,961 \\
13 & $X_{3} X_{4}$ & 557,176 & 29 & $X_{1} X_{3} X_{4} X_{5}$ & 523,221 \\
14 & $X_{3} X_{5}$ & 559,353 & 30 & $X_{2} X_{3} X_{4} X_{5}$ & 527,998 \\
15 & $X_{4} X_{5}$ & 566,805 & 31 & $X_{1} X_{2} X_{3} X_{\mathbf{4}} \boldsymbol{X}_{\mathbf{5}}$ & 464,532 \\
16 & $X_{1} X_{2} X_{3}$ & 542,370 & & & \\
\hline
\end{tabular}

Berdasarkan Tabel 4, dipilih model ke 31 sebagai model terbaik karena memiliki nilai KICC terkecil, yaitu sebesar 464,532. Variabel prediktor terdiri dari angka harapan hidup $\left(X_{1}\right)$, tingkat pengangguran terbuka $\left(X_{2}\right)$, pengeluaran per kapita $\left(X_{3}\right)$, tingkat kemiskinan $\left(X_{4}\right)$, dan pendapatan asli daerah $\left(X_{5}\right)$.

\section{Pengujian Signifikansi Model Regresi multivariat}

\section{Pengujian Signifikansi Model Secara Serentak}

Pengujian secara serentak dilakukan dengan menggunakan uji Wilk's Lambda pada persamaan (6), sehingga diperoleh: 


$$
\begin{aligned}
\Lambda & =\frac{|E|}{|E+H|}=\frac{\left|Y^{T} Y-\hat{\beta}^{T} X^{T} Y\right|}{\left|Y^{T} Y-n \bar{y} \bar{y}^{T}\right|} \\
& =\frac{381,7998}{39461000} \\
& =0,000009676
\end{aligned}
$$

Berdasarkan hasil analisis diperoleh nilai $\Lambda_{\text {hitung }}$ sebesar 0,000009679. Karena nilai $\Lambda_{\text {hitung }}<\Lambda_{0,05,3,5,4}$, maka berhasil menolak $\mathrm{H}_{0}$ sehingga dihasilkan paling sedikit terdapat satu parameter yang signifikan terhadap model.

\section{Pengujian Signifikansi Model Secara Parsial}

Pengujian parsial dilakukan dengan menggunakan uji Wilk's Lambda pada persamaan (7), dimana $\Lambda_{\text {tabel }}=\Lambda_{0,05,3,1,4}=0,034$

TABEL 5. Nilai Uji Signifikansi Model Secara Parsial

\begin{tabular}{cc}
\hline Prediktor & Wilk's Lambda \\
\hline$X_{1}$ & 0,000127473 \\
$X_{2}$ & 0,000015256 \\
$X_{3}$ & 0,000044388 \\
$X_{4}$ & 0,000026642 \\
$X_{5}$ & 0,000015157 \\
\hline
\end{tabular}

Berdasarkan Tabel 5 nilai Wilk's Lambda $\left(\Lambda_{\text {hitung }}\right)<\Lambda_{\text {tabel }}$ maka $\mathrm{H}_{0}$ ditolak sehingga setiap variabel prediktor berpengaruh signifikan terhadap variabel-variabel respon secara parsial.

\section{Pengujian Asumsi Residual}

\section{Uji Asumsi Residual Identik}

Dengan menggunakan software IBM SPSS Statistics 22, diperoleh nilai statistik uji Box's-M sebagaimana Tabel 6:

TABEL 6. Nilai Statistik Uji Box's-M

\begin{tabular}{ll}
\hline Test Results & \\
\hline Box's M & 59.422 \\
Approx & 29.290 \\
df1 & 2 \\
df2 & 1640.250 \\
Sig. & .000 \\
\hline
\end{tabular}

Berdasarkan Tabel 6 diperoleh nilai statistik uji Box's-M sebesar 59.422, serta diperoleh nilai $p$ value sebesar 0,000. Karena nilai $p$-value lebih kecil dari 0,05 maka tolak $\mathrm{H}_{0}$ yang berarti matriks varian-kovarian residual tidak homogen dan dapat disimpulkan bahwa residual tidak identik.

\section{Uji Asumsi Residual Independent}

Untuk pengujian asumsi residual independent digunakan uji Bartlett Sphericity pada persamaan (8), sehingga diperoleh:

$$
\begin{aligned}
X_{\text {hitung }}^{2}= & -\left(n-1-\frac{2 q+5}{6}\right) \ln |\boldsymbol{R}| \\
& =-\left(10-1-\frac{2(3)+5}{6}\right) \ln \left|\begin{array}{ccc}
1 & -0,983 & -0,474 \\
-0,983 & 1 & 0,458 \\
-0,474 & 0,458 & 1
\end{array}\right| \\
& =26,131
\end{aligned}
$$


Berdasarkan perhitugan di atas, diperoleh nilai $X_{\text {hitung }}^{2}$ sebesar 26,131. Karena nilai $X_{\text {hitung }}^{2}$ lebih besar dari nilai $X_{0,05,3}^{2}$ maka kesimpulannya tolak $\mathrm{H}_{0}$ sehingga residual data bersifat dependent.

\section{Uji Asumsi Residual Berdistribusi Normal}

Pengujian residual berdistribusi normal dilakukan dengan prosedur yang sama dengan pengujian variabel respon berdistribusi normal sebagaimana persamaan (9).

Berdasarkan hasil pengujian yang dilakukan, maka didapatkan nilai $d_{i}^{2}$ sebagai berikut:

TABEL 7. Statistik Uji untuk $\boldsymbol{d}_{\boldsymbol{i}}^{2}$ Residual

\begin{tabular}{cccc}
\hline $\mathbf{i}$ & $\boldsymbol{d}_{\boldsymbol{i}}^{\mathbf{2}}$ & $\mathbf{i}$ & $\boldsymbol{d}_{\boldsymbol{i}}^{\mathbf{2}}$ \\
\hline 1 & 1,37568 & 6 & 0,27216 \\
2 & 1,80160 & 7 & 5,77536 \\
3 & 3,70646 & 8 & 0,02506 \\
4 & 3,29490 & 9 & 0,13474 \\
5 & 1,06875 & 10 & 0,54528 \\
\hline
\end{tabular}

Berdasarkan Tabel 7 nilai $d_{i}^{2}<X_{3, \frac{1}{2}}^{2}=2,366$ terhadap 7 pengamatan atau sebesar $70 \%$ dari 10 pengamatan. Berdasarkan hal tersebut, maka gagal menolak $\mathrm{H}_{0}$ sehingga residual dikatakan berdistribusi normal.

\section{Hubungan Antar Variabel Dalam Model}

Pada regresi multivariat, nilai yang digunakan untuk mengetahui besarnya hubungan antara variabel respon dan variabel prediktor adalah eta square lambda pada persamaan (10), sehingga diperoleh:

$$
\begin{aligned}
\eta_{\Lambda}^{2} & =1-\Lambda_{\text {hitung }} \\
& =1-0,000009676 \\
& =0,999990324 \\
& =99,99 \%
\end{aligned}
$$

Berdasarkan peritungan diatas, diperoleh nilai $\eta_{\Lambda}^{2}$ sebesar 0,999990324 yang berarti variabel prediktor mampu menjelaskan data pada variabel respon sebanyak 99,99\%. Selanjutnya $0,01 \%$ dijelaskan oleh variabel-variabel prediktor lain yang tidak diteliti. Dapat disimpulkan bahwa semua variabel yang terdapat didalam model berpengaruh untuk mengukur kesejahteraan masyarakat di provinsi Nusa Tenggara Barat.

\section{Interpretasi Model Regresi multivariat}

Model terbaik dari tingkat kesejahteraan masyarakat di Provinsi NTB menggunakan model regresi multivariat dengan metode pemilihan Kullback's Information Criterion Corrected (KICC), adapun estimasi model yang diperoleh adalah sebagai berikut:

$Y_{1}=-32,4987+2,2106 X_{1}+6,6420 X_{2}-7,6274 X_{3}-1,4584 X_{4}-0,4045 X_{5}$
$Y_{2}=-7,0798-3,0548 X_{1}-11,9527 X_{2}+15,5082 X_{3}+2,4070 X_{4}+0,8703 X_{5}$
$Y_{3}=-48,9707+1,6146 X_{1}-0,5331 X_{2}+0,8945 X_{3}-0,1140 X_{4}+0,0370 X_{5}$

Berdasarkan interpretasi disimpulkan bahwa untuk meningkatkan kesejahteraan masyarakat jika ditinjau dari faktor pertumbuna ekonomi dan Indeks Pembangunan Manusia, maka pemerintah kabupaten dan kota di NTB harus mengurangi tingkat pengangguran terbuka, dan persentase kemiskinan. Di sisi lain pemerintah kabupaten dan kota di NTB harus memperbesar angka harapan hidup, pengeluaran per kapita, dan pendapatan asli daerah. 


\section{PEMBAHASAN}

Pengujian signifikansi model secara serentak dilakukan dengan menggunakan uji Wilk's Lambda. Kriteria uji yang diinginkan adalah $\Lambda_{\text {hitung }}<\Lambda_{\text {tabel }}$. Dari hasil analisis didapatkan nilai $\Lambda_{\text {hitung }}=0,0000096676$. Karena $\Lambda_{\text {hitung }}<\Lambda_{\text {tabel }}$, sehingga dihasilkan paling sedikit terdapat satu parameter yang signifikan secara serentak terhadap model (variabel prediktor berpengaruh secara signifikan terhadap model).

Pengujian signifikansi model secara parsial juga dilakukan dengan menggunakan uji Wilk's Lambda. Kriteria uji yang diinginkan adalah $\Lambda_{\text {hitung }}<\Lambda_{\text {tabel }}$. Dari hasil analisis didapatkan nilai $\Lambda_{\text {hitung }}<\Lambda_{\text {tabel }}$ dari masing-masing variabel prediktor, sehingga dapat disimpulkan bahwa variabel prediktor berpengaruh signifikan terhadap variabel-variabel respon secara parsial.

\section{KESIMPULAN}

Variabel-variabel yang dapat dijadikan indikator untuk mengenalisis tingkat kesejahteraan masyarakat di Provinsi NTB menggunakan model regresi multivariat multivariat antara lain untuk variabel respon terdiri dari tingkat Pertumbuhan Ekonomi $\left(\mathrm{Y}_{1}\right)$, tingkat Produk Domestik Regional Bruto per kapita $\left(\mathrm{Y}_{2}\right)$, dan Indeks Pembangunan Manusia $\left(\mathrm{Y}_{3}\right)$. Untuk variabel prediktor terdiri dari angka harapan hidup $\left(\mathrm{X}_{1}\right)$, tingkat pengangguran terbuka $\left(\mathrm{X}_{2}\right)$, pengeluaran per kapita $\left(\mathrm{X}_{3}\right)$, tingkat kemiskinan $\left(\mathrm{X}_{4}\right)$ dan pendapatan asli daerah $\left(\mathrm{X}_{5}\right)$.

Bentuk model regresi multivariat multivariat yang cocok digunakan untuk menganalisis tingkat kesejahteraan masyarakat di Provinsi Nusa Tenggara Barat adalah:

$Y_{1}=-32,4987+2,2106 X_{1}+6,6420 X_{2}-7,6274 X_{3}-1,4584 X_{4}-0,4045 X_{5}$

$Y_{2}=-7,0798-3,0548 X_{1}-11,9527 X_{2}+15,5082 X_{3}+2,4070 X_{4}+0,8703 X_{5}$

$Y_{3}=-48,9707+1,6146 X_{1}-0,5331 X_{2}+0,8945 X_{3}-0,1140 X_{4}+0,0370 X_{5}$

dan besarnya hubungan antara variabel respon dan variabel prediktor diperoleh nilai $\eta_{\Lambda}^{2}=$ 0,999990324. Hal ini berarti model dapat menjelaskan informasi data sebesar 99,99\%.

\section{DAFTAR PUSTAKA}

BPS. (2016). Statistik Daerah Provinsi Nusa Tenggara Barat 2016. Mataram: Badan Pusat Statistik Provinsi Nusa Tenggara Barat.

Hafidi, B., \& Mkhadri, A. (2006). A Corrected Akaike Criterion Based on Kullback's Symmetric Divergence: Application in Time Series, Multiple and Regression. Computational Statistiks and Data Analysis, 50(2). 1524-1550.

Johnson, R.A., \& Wichern, W.D. (2007). Applied Statistikal Analysis. New Jersey: Prentice Hall.

Limbong, D., \& Setyawan, Y. (2018). Pe31milihan Model Regresi multivariat Terbaik dengan Kriteria Kullback's Information Criterion Correction (KICC) (Studi Kasus: Tingkat Kesejahteraan Masyarakat di Provinsi Sumatera Utara). Jurnal Statistika Industri dan Komputasi, 3(2). 42-53.

Morrison, D.F. (2005). Statistikal Methods (Fourth Edition). The Wharton School University of Pennsylvania.

Rencher, A.C. (2002). Methods of Analysis (Second Edition). John Wiley \& Sons, Inc. New York.

Rosni. (2017). Analisis Tingkat Kesejahteraan Masyarakat Nelayan di Desa Dahari Selebar Kecamatan Talawi Kabupaten Batubara. Jurnal Geografi, 9(1).53-66. 
Sinaga, A.A.P. (2016). Analisis Faktor-Faktor yang Mempengaruhi Kesejahteraan Masyarakat di Kota Medan (Studi Kasus Usaha Kecil dan Menengah). Jurnal Ilmiah Methonomi, 2(1). $1-9$.

Sumaya. (2014). Pemilihan Model Terbaik Pada Analisis Regresi multivariat Linier. Jurnal Mahasiswa Statistik, 2(6). 433-436.

Tiro, M.A. (2007). Statistika Terapan untuk Ekonomi dan Ilmu Sosial. Makassar: Andira Publisher.

Mardianto, M.F.F., \& Wahyuningsih, N. (2013). Model Regresi multivariat untuk Menentukan Tingkat Kesejahteraan Kabupaten dan Kota di Jawa Timur. Jurnal Sains dan Seni Pomits, 2(1). 2337-3520. 